\title{
ÁLLÓHENGERES KONDENZÁTOR REZGÉSTANI VIZSGÁLATA
}

\author{
Kriston Balázs \\ MSc hallgató, Energetikai és Vegyipari Gépészeti Intézet \\ 3515 Miskolc, Miskolc-Egyetemváros, e-mail: kristonbalazs7@gmail.com \\ Pusztai Tamás \\ PhD hallgató, Energetikai és Vegyipari Gépészeti Intézet \\ 3515 Miskolc, Miskolc-Egyetemváros, e-mail:pusztai@uni-miskolc.hu \\ Petrik Máté \\ tanársegéd, Energetikai és Vegyipari Gépészeti Intézet \\ 3515 Miskolc, Miskolc-Egyetemváros, e-mail: petrik@uni-miskolc.hu
}

\begin{abstract}
Absztrakt
A nyomástartó edények egyik leggyakrabban használt típusa a höcserélö, amelyben höátadási müvelet történik. A készülékben a nagyobb entalpiájú közeg energiát ad át a másik, kisebb entalpiájú közegnek. Ezeket a höcserélöket hütötechnikában, höerögépekben, kohászatban, a vegyiparban és még számos iparágban használják. Jelen tanulmány egy ilyen speciális höcserélö szerkezet, egy állóhengeres kondenzátor sajátfrekvenciájának elméleti és gyakorlati vizsgálatát mutatja be VEM szimuláció segitségével.
\end{abstract}

Kulcsszavak: szilárdsági méretezés, végeselem analizis, sajátfrekvencia

\begin{abstract}
One of the most commonly used pressure vessels are the heat exchangers, in which the heat transfer operation takes place, the higher enthalpy medium transmits energy to the other lower enthalpy medium. These equipment are used in refrigeration systems, heat engines, metallurgy, chemical and many other industries. This study presents a theoretical and practical investigation method of the eigenfrequency of such a special heat exchanger, a vertical condensator.
\end{abstract}

Keywords: design, finite element analysis, eigenfrequency

\section{Bevezetés}

A hőcserélő szerkezetek a vegyipar és rokon ágazatainak igáslovainak is tekinthetők. Vegyipari folyamatok az esetek kis részében mennek végbe normál, légköri viszonyok között, ettől eltérö hőmérsékletet és nyomást igényelnek. Ahhoz, hogy ez teljesíthető legyen, egy arra a célra szánt készülékben, mely jelen esetben egy hőcserélő lesz, valamilyen segédenergiával a megfelelő mennyiségü hőenergia kerül átadásra. A hőcserélők rendkívül sokfélék lehetnek: a legegyszerübbek a cső a csőben hőcserélők [1] kis tömegáramok és nagy hőmérséklet-érzékenység esetén; a legelterjedtebb a csőköteges hőcserélők [2] nagy tömegáramokhoz; lemezes hőcserélők [3] kis tömegáramok és a kisebb térfogatok esetén; valamint bordáscsöves hőcserélők[4], ha az egyik közeg gáz fázisú. Vannak egészen speciális kialakítások is, például a nem newtoni folyadékokhoz kifejlesztett kapartfalú hőcserélök [5].

A hőmérséklet mellett a másik legfontosabb állapotjelző a nyomás, ezek együttesen határozzák meg a kezelendő fluidumok fázisállapotát és anyagtulajdonságait. Mivel ezek a közegek az esetek 
túlnyomó többségében túlnyomás alatt állnak, olyan készüléket kell tervezni hozzájuk, amelyekkel a készülék falában kialakuló feszültségek nem haladják meg a megengedett feszültség értékét. Azonban ezeket a feszültségeket a típusoktól függően osztályozni kell, mivel nem egyforma veszélyt jelentenek a készülékre. A következő alfejezet ezeket a feszültségkategóriákat mutatja be.

\subsection{Feszültségtípusok}

Az első feszültségtípus az elsődleges feszültségek témaköre. Ezek azok a feszültségek, melyek a készülék falára ható terhelésekből (nyomás, erő, nyomaték) származnak, és megfelelnek a mechanika egyensúlyi törvényeinek. Membránfeszültségi (vagyis kéttengelyü) feszültségállapotot feltételezve tangenciális, $\sigma_{t}$, (érintő irányú) és axiális, $\sigma_{a}$, (tengelyirányú) feszültségek alakulnak ki. A vizsgált kondenzátor esetén a köpeny falában a köpenytéri nyomással, $p$, és a falvastagsággal, $e_{a}$, arányosak ezek a feszültségek. $D_{e}$ a hengeres rész külső átméröjét jelenti.

$$
\begin{aligned}
\sigma_{t} & =\frac{p \cdot D_{e}}{2 \cdot e_{a}} \\
\sigma_{a} & =\frac{p \cdot D_{e}}{4 \cdot e_{a}}
\end{aligned}
$$

Mivel ezek a feszültségek a nyomásterhelésből származnak, és az egész héjra hatnak, a legveszélyesebb feszültségekként kell rájuk tekinteni, így ezeket a megengedett feszültséghez kell viszonyítani. Az alátámasztások következtében kialakuló hajlítófeszültségek is az elsődleges feszültségek közé tartoznak, azonban ezek esetén a kialakuló feszültségek ferdeszimmetrikusak, ́́gy az egyik szálban húzófeszültségként jelennek meg, a másikban pedig nyomófeszültségként. Mindkét esetben szuperponálódnak a nyomásból származó membránfeszültségre, azonban míg az első esetben plusz terhelésként, addig a második esetben terheléscsökkenésként jelentkeznek. Ennek következtében a hajlítófeszültségek és membránfeszültségek összegét másfélszeres megengedett feszültségig, gyakorlatilag a folyáshatár értékéig engedhetők meg.

Másodlagos feszültségek közé azok a feszültségek sorolhatók, melyek a különböző falvastagságok, kényszerek, különböző rugalmassági modulusok használatából, vagy eltérő hőtágulási együtthatók esetén alakulnak ki. Ezek a feszültségek önhatárolók, képlékeny alakváltozással kiegyenlítődnek. Mivel a készülék viszonylag kis térfogatára vannak hatással, ezek az alakváltozások megengedhetők.

A harmadik nagy feszültség-kategória a csúcsfeszültségek témaköre. Ezen feszültségek nagyon kis térfogatra korlátozódnak, tervezési állapotban nem is lehet az értéküket meghatározni, csak végeselemes (VEM) analízissel, melyet a következő fejezet tárgyalja. Ezeket a csúcsfeszültséggel kombinált feszültségeket háromszoros megengedett feszültséget, vagyis kétszeres folyáshatár értéket vehetnek fel maximálisan, és a kifáradási folyamatban van szerepük, a fáradásos törés kiindulópontját jelentik.

Ezek a feszültségkategóriák minden tervezési szabványban, tervezési elő́rásban (EN 13445, ASME Div VIII, AD Merkblatt) szerepelnek, kiszámítási módjuk kódonként változik, de mindegyik azonos mechanikai alapokon nyugszik. 


\subsection{Periodikus igénybevételek}

A periodikus mozgások közös tulajdonsága, hogy a mozgás alakja megismétlődik egy időintervallum után, és ez az ismétlődés a végtelenségig folytatódik. Az ismétlés idejét a rezgés periódus idejének nevezzük és $T_{0}$-val jelöljük. A periodikus jelenséget az $f(t)$ függvénnyel jellemezzük, ahol $t$ az időt jelenti, és $n$ egész szám értéke - és $+\infty$ között változhat. Az 1. ábra egy ilyen, tisztán periodikus jelet reprezentál.

$$
f(t)=f\left(t+n \cdot T_{0}\right)
$$

Gyakorlati szempontból az egyik legfontosabb periodikus mozgás a rezgések témaköre. A rezgés egy oszcilláció, azaz ismétlődő mozgást jelent egy egyensúlyi pont körül. Egyensúlyi pontnak nevezzük, azt a helyt, ahol a rezgést gerjesztő erő egyenlő nullával. Egy test rezgőmozgása teljes mértékben leírható hat egyedi mozgás kombinálásával.

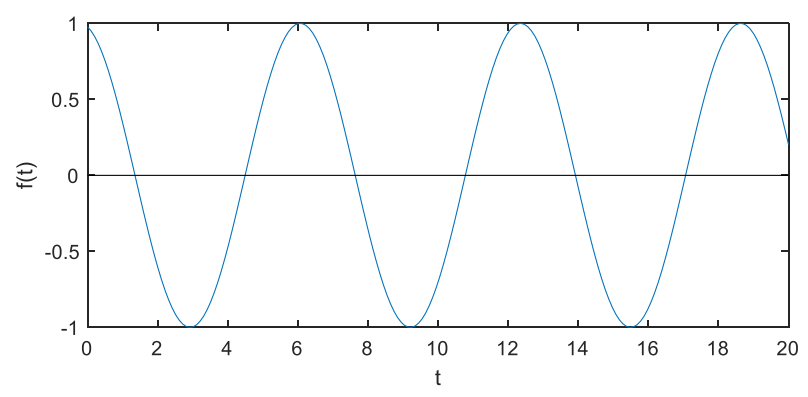

1. ábra. Időben változó periodikus jelenség függvénye

Ez a hat mozgás két nagy típusra bontható:

- transzlációs (haladó) mozgás, amelyeket a tér három (x, y és z tengelyek) irányában,

- rotációs (forgó) mozgás $\mathrm{x}, \mathrm{y}$ és $\mathrm{z}$ tengelyek körül értelmezünk.

Minden test komplex, összetett mozgását a fenti hat komponensre szét lehet szedni, illetve azok eredőjeként fel lehet írni. Az ilyen eseteket hat szabadságfokkal szoktuk jellemezni.

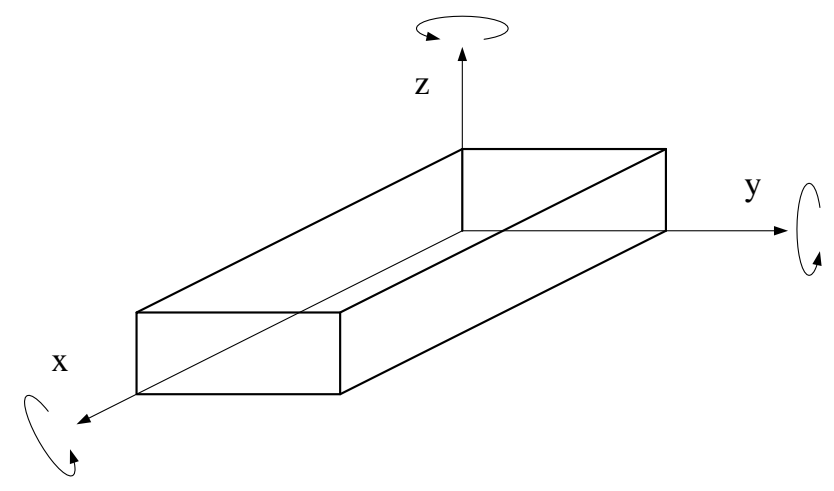

2. ábra. Hat szabadságfokú mozgás 
A rezgések számtalan esetben lehetnek kedvező jelenségek. Ilyenek például a pengetős, fúvós hangszerek, vagy akár a hangszórók is. Ezek müködésének alappillére a rezgés.

Azonban sok esetben (föleg müszaki életben) a rezgések nagyon veszélyesek és a minimalizálásukra kell törekedni, mivel energiaveszteséggel, zajjal, instabilitással, kopással járnak, amik a szerkezet teljes tönkremenetelét is okozhatják.

A rezgéseket számos dolog gerjesztheti, például (rosszul rögzített forgórészek, nem megfelelően illesztett felületek stb.). Esetünkben a hőcserélőnkhöz kötött szivattyú.

Amennyiben a kitérés lekorlátozódik egy koordinátára, akkor egyszabadságfokú rezgőmozgásról beszélünk. Ilyen mozgásra jó példa lehet a tömeg-rugó rendszer. Egyszerü tömeg-rugó rendszer esetén, ahol nincsen csillapítás, se külső kényszer erő, az $m$ tömegü testet $x$ távolságra elmozdítva az egyensúlyi ponttól, a rugó $F$ erővel fogja az egyensúlyi pont felé visszahúzni a testet, melynek $k$ a rugó rugóállandója.

$$
F=k \cdot x
$$

Newton második axiómáját alkalmazva megkapjuk a tömegpont mozgásegyenletét:

$$
m \cdot \ddot{x}=-k \cdot x
$$

Ez egy másodrendủ, lineáris, állandó együtthatójú, homogén, közönséges differenciál-egyenlet, melynek általános megoldása:

$$
x(t)=C_{1} \cdot \sin \omega_{0} t+C_{2} \cdot \cos \omega_{0} t=A \cdot \sin \left(\omega_{0} t+\delta\right)
$$

A megoldás első felében lévő $C_{1}$ és $C_{2}$ tényezők, valamint a másodikban lévő $A$ és $\delta$ tényezők integrációs állandók. A kitérés maximális értéke az amplitúdó $(A), \delta$ a kezdőfázis, $\omega_{0}$ pedig a körfrekvencia.

\subsection{Sajátfrekvencia}

Sajátfrekvencia alatt azt a frekvenciát értjük, amivel egy gerjesztett rezgést végző test vagy egy összetett szerkezet rezeg a külső gerjesztés lekapcsolása után. A sajátfrekvenciát csak a rendszer saját tulajdonságai szabják meg. Ezen tartományban való rezgés során a test nagyobb amplitúdóval mozog, mint más frekvenciák esetében. Az összetett szerkezeteknek több sajátfrekvenciája is van, melyek közül azzal rezeg, amelyhez legközelebbi frekvenciájú gerjesztést kap. Mind statikus szerkezetek (készülékek, tartószerkezetek, hidak), mind pedig mozgó szerkezetek (gépek, jármüvek) esetén figyelembe kell venni a tervezés során. Ezek a sajátfrekvenciák csak rendkívül egyszerủ testek esetén határozhatók meg analitikus úton, összetett szerkezeteknél kísérleteket vagy végeselemes szimulációt igényelnek.

A hőcserélő analízise esetén ez a gerjesztés származhat a technológiai közegek áramlását biztosító centrifugál szivattyúk rezgéséből. Számos kísérleti vizsgálat foglalkozott ezeknek a gépeknek a vizsgálatával [6]-[8]. 


\section{Vizsgált szerkezet bemutatása}

A vizsgált szerkezet egy merev csőköteges hőcserélő, melynek funkciója a csőtérbe érkező $10^{\circ} \mathrm{C}$-os etanol felmelegítése $64^{\circ} \mathrm{C}$-ra a köpenytérbe érkező göz segítségével. A hőátadás során a köpenytérben áramló gőz kondenzálódik. A kondenzátor pozícióját tekintve, vertikális elhelyezkedésű, rögzítését a köpenyen lévő paták segítségével lehet megoldani. A kondenzátor 3D-s modelljét a 3. ábra mutatja.

A kondenzátor műveleti adatait az 1. táblázat tartalmazza. A kondenzátorban lejátszódó folyamat során 7910 kJ hőenergia kerül átadásra egységnyi idő alatt. A geometriai adatok meghatározása során a szükséges szilárdsági számításokat az MSZ-EN-13445-3-as szabvány alapján végeztük. A kondenzátor alapanyaga 1.4401-es acél. A szilárdsági számításokhoz szükséges adatokat lemez alapanyag esetén az MSZ EN 10028-7-es szabványából, varratmentes cső esetén pedig az MSZ EN 10216-5-ös szabványból alkalmaztuk.

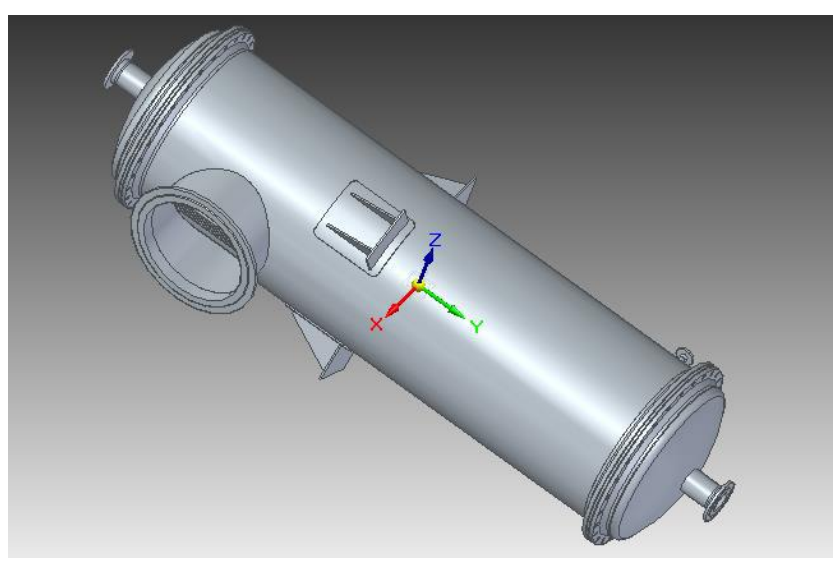

3. ábra. Kondenzátor $3 D$-s modellje

1. táblázat. Müveleti adatok

\begin{tabular}{|l|c|c|c|c|c|}
\hline & Közeg & $T_{b e}\left[{ }^{\circ} \mathrm{C}\right]$ & $T_{k i}\left[{ }^{\circ} \mathrm{C}\right]$ & $m_{b e}[\mathrm{~kg} / \mathrm{s}]$ & $p\left[\mathrm{bar}_{\mathrm{g}}\right]$ \\
\hline Csötér & Etanol & 10 & 64 & 64 & 3,5 \\
\hline Köpenytér & Vízgöz & 140 & 140 & 3,71 & 4 \\
\hline
\end{tabular}

A höcserélő $310 \mathrm{db}$ DN20-as csövet tartalmaz, melyek 2,8 m hosszúak. A csövek falvastagsága 2 mm. A hőcserélö köpenye DN900-as átméröjü cső, melynek falvastagsága 7,1 mm, hossza pedig 2,8 m. A hőcserélö köpenyén helyezkedik el a DN600-as méretü gőz bevezető csonk és a DN25-ös kondenzátum elvezető csonk. A hőcserélő $2 \mathrm{db}$ szabványos sekélydomború zárófelülettel van lezárva, melyeken a DN125-ös méretü etanol be- és kivezető csonkok találhatóak. A hőcserélő 3 patával kerül majd rögzítésre, melyek $120^{\circ}$-os osztásban helyezkednek el a köpenyen.

\section{Kondenzátor VEM vizsgálata}

A kondenzátor VEM vizsgálatához az ANSYS Modal nevű programját használtuk, melyben a geometria sajátfrekvenciája szimulálható. A szimuláció modellfáját a 4. ábra mutatja be. A 3D-s geometria Solid Edge-ben lett létrehozva. 
A végeselem szimulációk három részből épülnek fel Pre-processing, Megoldás, Post-processing.

- Pre-processing: Első lépésként magát a szerkezet alapanyagát és azok jellemzőit definiáljuk. A második lépésben a geometriát határozzuk meg. A geometria definiálása után a Model menüpontban fogjuk a vizsgálathoz szükséges előkészületeket elvégezni, majd magát a szimulációt lefuttatni. Először a végeselem-hálót hozzuk létre, majd miután definiáljuk az egyes megfogásokat és terheléseket a geometrián.

- Megoldás: Ha ezekkel készen vagyunk, a Solution pontban a Solve lehetőségre kattintva, lefuttatjuk a szimulációt.

- Post-processing: Majd a fejléc legalsó sorában lévő menüpontok közül kiválasztjuk, hogy mely eredményeket szeretnénk kiíratni, táblázatos vagy grafikus formában.

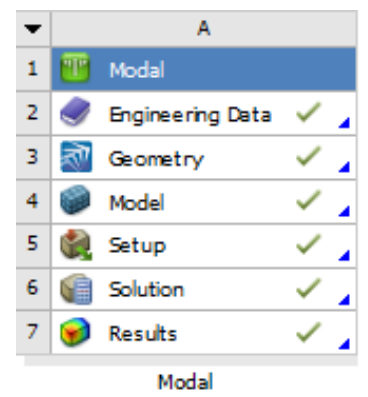

\section{4. ábra. Szimulációs modellfa}

\subsection{Végeselemes háló generálása}

A haló megalkotásánál szembe kerülünk azzal a problémával, hogy a kondenzátor nagy méreteiből adódóan a hálót alkotó cellák száma meghaladta a 19 millió darabot. A grafikus megjelenítőn látható volt, hogy az elemszámok körülbelül 95\%-át a 310 darab csőből álló csőköteg teszi ki. Az elemszámok csökkentésére két lehetőség állt rendelkezésre. Az egyik a cellák méretének növelése, ezzel kockáztatva, hogy a kapott eredmények még távolabb legyenek a valóságtól. A második pedig a csőköteg helyettesítése. A második lehetőséget választva eltávolításra kerültek a belső csövek, így az elemszám 260 ezer darabra csökkent.

\subsection{Peremfeltételek definiálása}

Üzemi állapotot feltételezve, a kondenzátor geometriáján hét helyen kell megfogást elöírni, az edény megtámasztására szolgáló három pata felfekvő felületére és a hőcserélő négy csonkjának csatlakozási felületére. Az alkalmazott megfogásokat az Hiba! A hivatkozási forrás nem található. baloldali ábráján zölddel jelölt felületei szemléltetik.

Mivel a csőköteget semmisnek tekintjük, a két csőkötegfal belső felületére „Frictionless Support” parancs néven kényszert írunk elö, így helyettesítve a belső csövek merevítő hatását. 

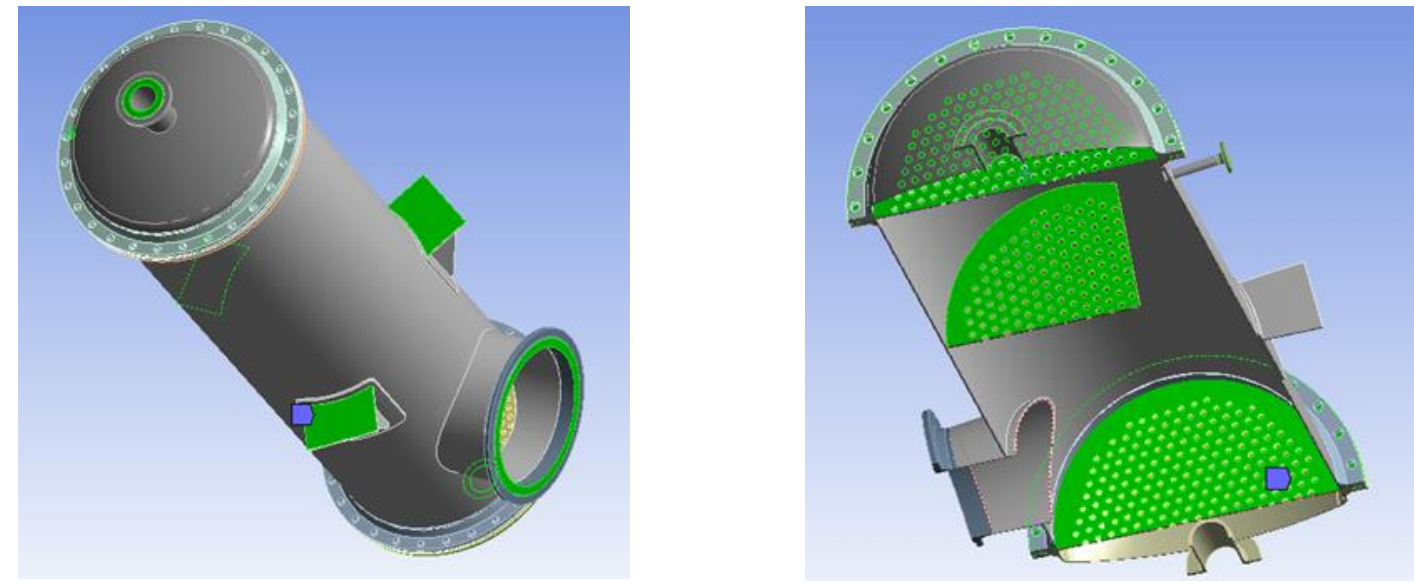

5. ábra. Kondenzátor megfogásai

Az 5. ábra jobb oldali ábrája szemlélteti az alkalmazott kényszereket. A szimuláció elvégzésekor eltekintettünk a csövek jelenlététől, és ezeket a csőkötegfalakon és terelölemezeken beállított merev megfogásokként modelleztük. Ez a megoldás egy durva megközelítést jelent, a valóságban kialakuló elmozdulások kisebbek lehetnek a szimulált értékeknél.

A megfelelő végeselemes háló legenerálása és a peremfeltételek definiálása után a szimuláció futtatható.

\section{Kondenzátor VEM vizsgálatának eredménye}

A szimuláció lefuttatása utána a sajátfrekvenciák számértékét táblázatos formában a 6 . ábra mutatja.

\begin{tabular}{|l|l|l|} 
& Mode & $\sqrt{\checkmark}$ Frequency $[\mathrm{Hz}]$ \\
\hline 1 & 1, & 239,56 \\
\hline 2 & 2, & 243,25 \\
\hline 3 & 3, & 286,52 \\
\hline 4 & 4, & 297,36 \\
\hline 5 & 5, & 306,98 \\
\hline 6 & 6, & 420,39 \\
\hline
\end{tabular}

6. ábra. A kondenzátor sajátfrekvenciái

Az egyes sajátfrekvencia értékekhez tartozó elmozdulásokat a következő felsorolásban ismertetjük.

Ghoneam és társai [7] eredményeiből látszik, hogy az általuk vizsgált szivattyú egyik sajátfrekvenciája $307,22 \mathrm{~Hz}$, mely az általunk vizsgált 5. sajátfekvenciához rendkívül közel esik, így elengedhetetlen ezen jellemzők vizsgálata.

\subsection{Az első sajátfrekvencia kiértékelése}

Ebben az esetben a sajátfrekvencia értéke $239,56 \mathrm{~Hz}$-re adódott. Ezen frekvencián történő rezonancia a tartály köpenyének $y$ irányú tengelye mentén egy $x$ irányú kihajlását idéz elő. Az elmozdulás a paták alsó részétől az alsó edényfenéken lévő csonkig tart. Ennek az oka, hogy a kondenzátor fentröl lefelé 
haladva nem szimmetrikus. Míg a felső részt egy DN125-ös és egy DN600-as csonk, valamint a stabilitás érdekében, a középvonaltól fölfelé, három, 100mm távolságra elhelyezett pata rögzíti, addig az alsó részt csak egy DN125-ös és egy DN25-ös csonk, illetve az edény belső részében elhelyezett terelőlemez merevíti, melyek hatása elenyésző.

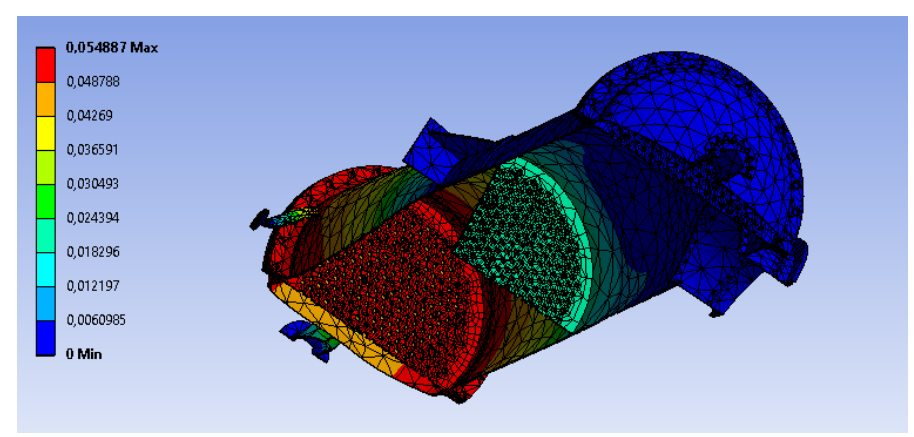

\section{7. ábra. A höcserélö elsö sajátfrekvenciájához tartozó elmozdulásállapot}

Ha hőcserélőnk metszetét vesszük, amelyet a 7. ábra szemléltet, láthatjuk, hogy a terhelés nem csak a köpenyt, hanem a terelőlemezek, a karimák és a csőkötegfal teljes egészét érinti. Az elmozdulások a köpeny alsó részénél, a karimák és a csőkötegfal csatlakozásánál tetőznek, és érik el az 5,4887 mm-es maximális értéket.

Mivel a hőcserélő egy több egységből felépülő összetett szerkezet, ezért a keletkezett igénybevételek sosem egyszerúek. A paták alsó részétől az alsó karimákig az igénybevétel szinte tiszta hajlítás, azonban az alsó etanol csonk, rögzítő hatása, és a kihajlás miatt az alsó edényfenék kidomborodásokat és mélyedéseket láthatunk, amelyek a húzás és vele ellentétes irányú nyomás következményei. A hőcserélőre ható igénybevételeket a 8. ábra szemlélteti. Annak érdekében, hogy ezek az elmozdulások számunkra is érzékelhető legyen, jelentős nagyítást alkalmaztunk.

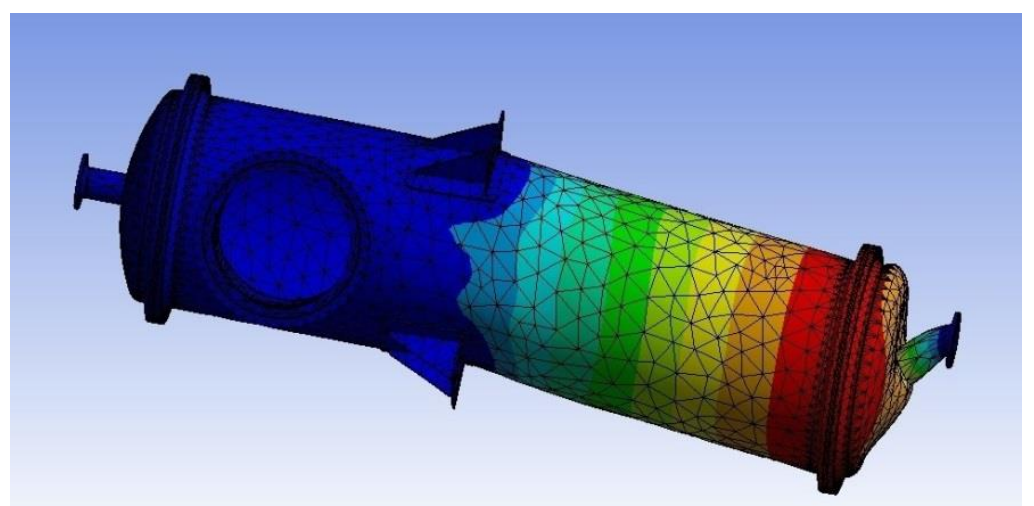

8. ábra. A höcserélö első sajátfrekvenciájához tartozó elmozdulás-állapot

\subsection{A második sajátfrekvencia kiértékelése}

A test második sajátfrekvenciája $243,25 \mathrm{~Hz}$ értéket veszi fel.

Ezen frekvencián történő rezgés során létrejövő folyamatok szinte majdnem minden pontban megegyeznek az első esetben tapasztaltakéval. 


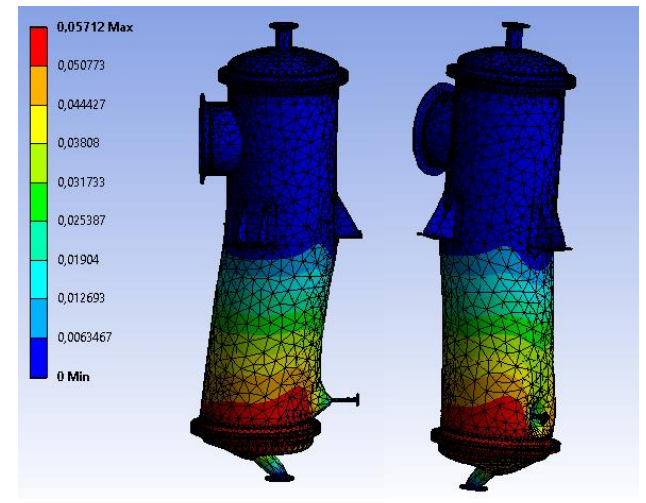

9. ábra. A höcserélö elmozdulás-állapota 2. sajátfrekvencia esetén

A rezgés a test teljes térfogata mentén $z$ irányba egy hajlítást okoz, amely a kondenzátorunk közepétől fokozatosan növekvő mértékủ elmozdulást hoz létre.

Ez a köpeny alsó végénél a karima és csőkötegfal csatlakozásánál tetőzik. Itt a maximális elmozdulás $5,712 \mathrm{~mm}$.

Az alsó edényfenék környezete az irányt leszámítva ugyanúgy viselkedik, mint ahogy azt az első esetben tapasztaltuk, kihajlás irányának változása miatt viszont a víz kilépő csonk és annak környezete máshogy reagál. Mivel a rezgés a karima tömítő felületére merőlegesen hat a testre, így a csonk és a köpeny hegesztési varrata mentén nem kihajlik, hanem húzódik és nyomódik, attól függően, hogy melyik irányba van a maximális kitérés.

\subsection{A harmadik sajátfrekvencia kiértékelése}

A harmadik esethez tartozó sajátfrekvencia érték 286,52 Hz.

Ha a testet alulról, az $\mathrm{x}, \mathrm{z}$ síkból nézzük, a grafikus munkalapon látható mozgásokból megállapítható, hogy a szivattyú által gerjesztett rezgés egyfajta csavaró hatással hat az edényre. Ez a csavarás az alsó edényfenéktől a paták és a DN600-as csonk kivételével az egész köpeny mentén a felső edényfenékig terheli az a szerkezetet, de nem ugyan akkora értékben.

Míg az edény alsó részében, az elemek jól láthatóan csak az y tengely körül forognak, addig a felső edényfenék környezetében, ez a csavarás veszít a nagyságából, és emellett megjelenik egy x irányú kihajlás is. Ahhoz, hogy ez a kihajlás jól látható legyen, $y, z$ síkból kell néznünk a testet. Láthatjuk, hogy a görbület a paták felső résztöl egészen a felső edényfenékig tart.

Mivel az edényünk nem szimmetrikus, a felső részen a jóval nagyobb rögzítés van, a DN600-as csonk méretéből adódóan nem engedi a köpeny elfordulását akkora mértékben, mint az a lenti részen is látható. (Az ábrán látható, hogy míg a kis csonk a köpennyel együtt elmozdul, a nagy csonk fixen áll.)

Az előző két esettől eltérően, ahol az elmozdulás inkább a felső részeken volt jelen, a terhelés szinte az egész testre kihat, legyen az kihajlás, csavarás vagy nyírás.

A maximális 5,27 mm-es elmozdulás értékek a karima és edényfenék csatlakozások peremén jönnek létre.

A felső edényfenéken lévő etanol belépési csonk környezetében a csavarás mellett az edényfenékben azt előző esetekhez hasonlóan egy húzó, nyomó terhelés jön létre. 


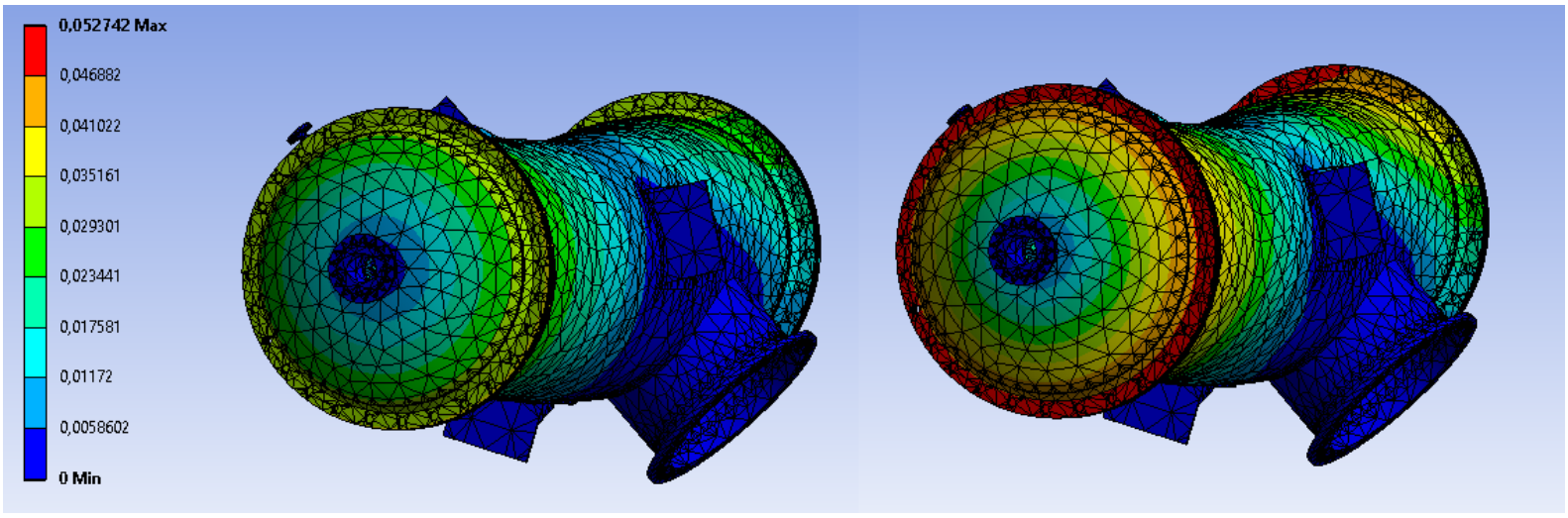

10. ábra. A höcserélö elmozdulás-állapota 3. sajátfrekvencia esetén

\subsection{A negyedik sajátfrekvencia kiértékelése}

A $297,36 \mathrm{~Hz}$ sajátfrekvencia értékhez tartozó terhelésállapot igénybevételek megjelenése szempontjából szinte majdnem megegyezik a harmadik esetben tapasztaltakéval.

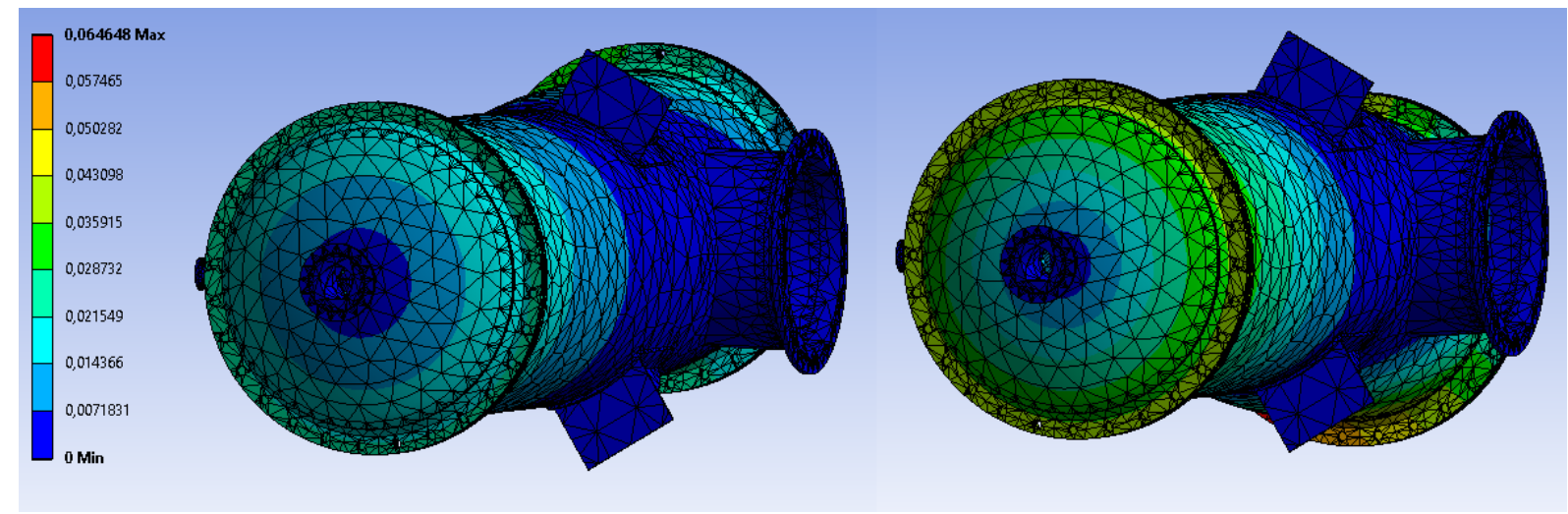

11. ábra. A höcserélö elmozdulás-állapota 4. sajátfrekvencia esetén

A csavarás az alsó edényfenéktől egészen a felső edényfenékig terheli a testet, különböző mértékkel, a patáktól felfele pedig az edény ismét egy kihajlást szenved el. Az előző esettel ellentétben, a maximális 6,46 mm-es elmozdulás csak az edény felső részében, a karima és csőkötegfal csatlakozásánál éri el.

\subsection{Az ötödik sajátfrekvencia kiértékelése}

A következő 306,98-as frekvenciaértékhez tartozó esetet több szemszögböl szeretném vizsgálni. Ha oldalról tekintünk a szerkezetünkre, egy tiszta hajlítást látunk, amely a patáktól felfelé az edény felső részében fejti ki hatását. Viszont, ha a DN600-as csonk és a köpeny találkozásánál lévő hegesztési varratot vizsgáljuk egy húzó/nyomó terhelés lesz jelen. 


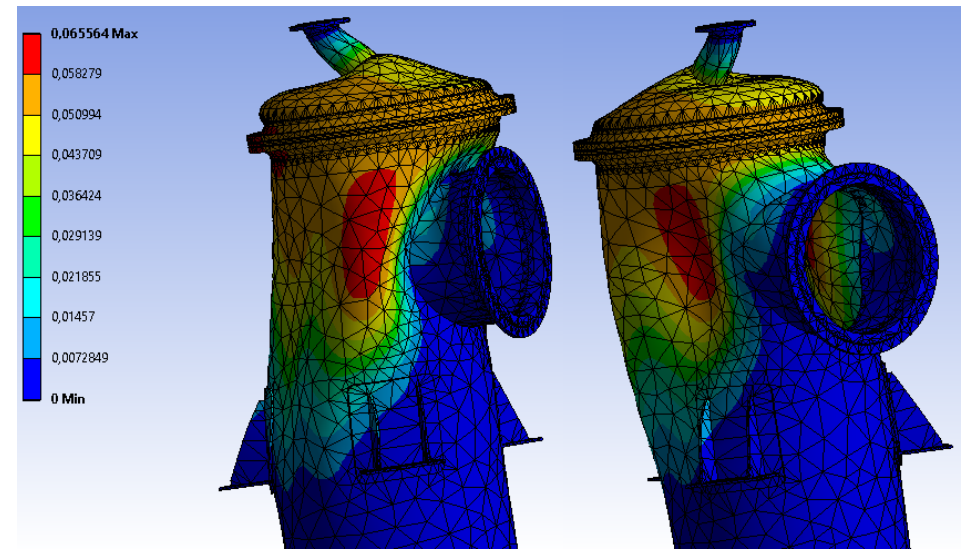

12. ábra. A höcserélö elmozdulás-állapota 5. sajátfrekvencia esetén

Mivel a csonk és a köpeny rögzítve van egymással, és a csonk végé is rögzítve van a hozzá csatlakozó csővezetékkel, ezért ez a két szerkezeti egység nem tud akkora mértékben kihajlani, mint a köpeny hátsó része. Így húzás esetén a köpeny átmérője mentén összeszükül, míg nyomásnál ráfekszik a csonkra, ezzel terhelve a hegesztési varratot és magát a csonkot.

A maximális elmozdulás nyomás esetén a köpenyhez csatlakozó karima csonkhoz átellenes pontjában és a köpenyen létrejövő domborodás mentén, míg húzás esetén a mélyedésekben jön létre.

\subsection{A hatodik sajátfrekvencia kiértékelése}

A hatodik sajátfrekvencia esetén a legnagyobb terhelést okozó igénybevétel az edény felső részén tetőző csavarás. Ez a legjobban a köpenyt és az edényfeneket összekapcsoló DN900-as karimán látható.

A karimák elfordulása miatt rögzítés nélküli esetben a hozzá kapcsolódó köpeny is vele együtt mozogna, azonban a rajta lévő csonk és paták megakadályozzák ennek az elfordulását. A rögzítések és a csavaró igénybevétel hatása miatt, a köpeny paták feletti részén kipúposodik.

Az elmozdulás a legnagyobb értékeket púpok csúcsában, valamint a mellettük lévő mélyedésekben veszi fel. A maximális elmozdulás érték 9,74 mm.

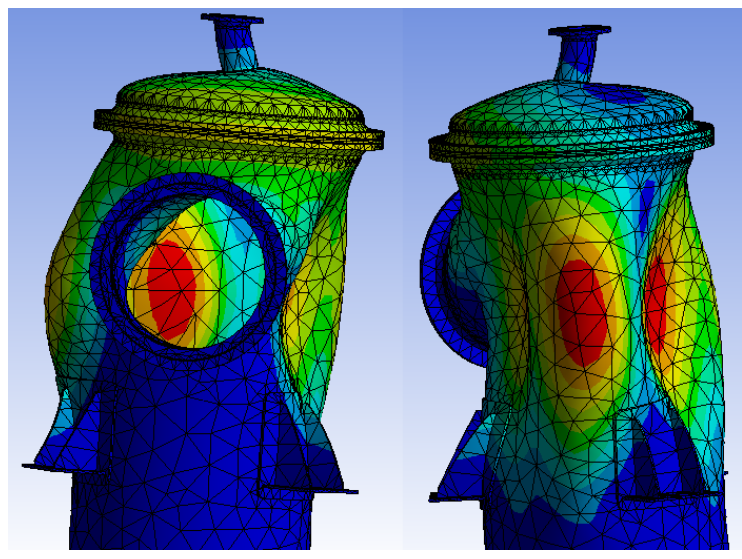

13. ábra. A höcserélö elmozdulás-állapota 6. sajátfrekvencia esetén 


\section{5. Összefoglalás}

A kapott eredményekből megállapítható, hogy a rezonancia egy komolyan figyelembe veendő tényező a tervezési folyamatnál, mivel a testet terhelő igénybevételek számos formában megjelenhetnek. Továbbá nehezíti a dolgot, hogy minden test más és más sajátfrekvenciával rendelkezik, ezért a hőcserélő geometriájának módosításával (több terelőlemez, párnalemezek, alátétlemezek) sem lehet kiküszöbölni ezt a jelenséget, mivel akkor egy másik hőcserélöt kapunk, ami szintén más sajátfrekvencia értékekkel fog rendelkezni. Ezáltal ismét ugyan abba a problémába ütköznénk.

Ebből adódóan a sajátfrekvencián történő rezgést, csak is a két frekvencia, a test saját és a gerjesztő frekvencia, eltolásával lehet kiküszöbölni, tehát a höcserélőhöz kapcsolt szivattyú által gerjesztett rezgések frekvencia tartományai minél messzebb kell, hogy essenek a szimulációval meghatározott sajátfrekvencia értékektől.

A szimulált eredményekhez képest a valóságban kisebb elmozdulások alakulhatnak ki. A tanulmányunkban a rossz mérnöki gyakorlat eszközeit feltételeztük, ennek a hatását vizsgáltuk.

\section{Irodalom}

[1] R. L. Mohanty and S. Bashyam, "Numerical analysis of double pipe heat exchanger using heat transfer augmentation techniques," no. 124, 2015.

[2] A. A. Shrikant, R. Sivakumar, N. Anantharaman, and M. Vivekenandan, "CFD simulation study of shell and tube heat exchangers with different baffle segment configurations," Appl. Therm. Eng., 2016.

[3] N. B. Chien et al., "Investigation of Experiment and Simulation of a Plate Heat Exchanger," Energy Procedia, vol. 158, no. 2018, pp. 5635-5640, 2019.

https://doi.org/10.1016/j.egypro.2019.01.575

[4] H. T. Chen, H. Y. Chou, H. C. Tseng, and J. R. Chang, "Numerical study on natural convection heat transfer of annular finned tube heat exchanger in chimney with experimental data," Int. $J$. Heat Mass Transf., vol. 127, pp. 483-496, 2018.

https://doi.org/10.1016/j.ijheatmasstransfer.2018.08.055

[5] T. Varga, G. Szepesi, and Z. Siménfalvi, "Horizontal scraped surface heat exchanger Experimental measurements and numerical analysis," Pollack Period., vol. 12, no. 1, pp. 107122, 2017. https://doi.org/10.1556/606.2017.12.1.9

[6] W. Y. Zhao, J. G. Ge, D. Ma, C. M. Li, and S. B. Bao, "Vibration analysis of large centrifugal pump rotors," IOP Conf. Ser. Mater. Sci. Eng. OPEN, vol. 52, p. 022033, 2013. https://doi.org/10.1088/1757-899X/52/2/022033

[7] M. Ghoneam, N. Water, R. Assistant, and N. Water, "Vibration analysis of centrifugal pump with variable speed drives," vol. 39, no. 3, pp. 565-579, 2011.

[8] C. Kang, Y. Zhang, Y. Xiong, and Q. Li, "Effects of the Pump Base on the Resonance of a Horizontal Condensate Pump Unit : A Case Study,” vol. 21, no. 4, pp. 633-644, 2018. 